\title{
A Possible Path to Change in U.S.-Iran Relations
}

\section{Mark Edmond Clark*}

In 1999, I visited Belgrade one month before the start of Operation ALLIED FORCE as a guest of the Yugoslav Ministry of Foreign Affairs to hear the perspectives of key officials on the possibility of a conflict between Yugoslavia and NATO. While there, I heard Yugoslav officials offer the singular perspective that NATO would not use force, and that threats to do so were used only to get the regime of Slobodan Milosevic to respond to diplomatic efforts by the United States and the European Union. On a basic level, there was simply a refusal to recognize that the threat of attack from NATO was real.

This past September and October, I visited Iran as the guest of its Ministry of Foreign Affairs, to get an idea of where key Iranian officials stood regarding the possibility of a war with the U.S. over its nuclear energy program. It is true that Iran's religious leadership is conservative on external and internal affairs, and gives considerable weight to the opinions of government hard-liners on foreign and security policy, but they also listen to moderate officials who want peace. Indeed, moderates even have the ear of the Ayatollah Ali Khamenei, who is the final arbiter on all matters of state. As Ali Jafari, of the Institute for Political and International Studies, stated, "The Guide provides audiences for all who can contribute on important issues." Unlike Yugoslavia, a true diversity of opinion exists among officials on the nature of the current crisis with the U.S. and, to some extent, the EU. Iran certainly is not the fundamentalist, Islamic monolith that it is portrayed to be.

By reviewing both conservative and moderate views held by officials in Iran on issues pertaining to U.S.-Iran relations, this split in opinion can be illuminated. Further, such a review would seem to support the idea that, through the establishment of a positive dialogue with moderate decision-makers and scholars in Iran, and the offer of support for some of their initiatives, it may yet be possible to resolve the current crisis.

\section{Nuclear Energy}

Iran's nuclear energy program began under the secular regime of Muhammad Reza Shah. At that time, in the late 1970s, the U.S. made no requests for the International Atomic Energy Agency (IAEA) to review Iran's program. After the Islamic revolution, however, Iran was placed under considerable scrutiny. The Iranians feel that they have been acting in good faith, and resent accusations of cheating. As A.A. Soltanieh, a renowned Iranian nuclear energy expert in the Ministry of Foreign Affairs, noted, "under the statutes of the very treaties used to demand further compliance and verification

Mark Edmond Clark is member and former fellow of the Council on Foreign Relations. His work concentrates on the Balkans, the Middle East and military affairs. His is a consultant for the Strategy Group and a frequent contributor to CIAO and other international affairs journals.

1 Personal conversation with Ali Jafari in October 2004. 
from them by inspection, Iran is allowed to engage in far greater activities to develop its program." Most recently, a uranium enrichment reading by the IAEA provoked an avalanche of calls from the U.S. for the review of Iran's activities. Mohamed ElBaradei, the director-general of the IAEA, erred when he claimed that astronomical levels of highly enriched uranium that were recorded at a nuclear facility in Iran were the result of enrichment activity. The IAEA found 70 percent enrichment through a swiping test, yet Iran admitted only to enriching to 1.2 percent as part of their program of centrifuge testing. Later, the IAEA confirmed the plausibility of Iran's argument that existing levels were the result of Iran's unwitting use of contaminated components acquired from China or Russia. Yet the U.S. ignored the report, and its accusations of cheating continue. Mahmood Sariolghalam of the National University of Iran opined, "Whenever we try to show that we are just like anyone else, the U.S. makes up things to avoid negotiations and this gives playing cards to the hard-liners in Iran."”

Conservatives in Iran believe that the U.S. has turned the nuclear energy issue into a political matter, and that no one should interfere with Iran's peaceful use of nuclear energy. Yet at the same time they are satisfied with the actions of the U.S. in insisting upon greater compliance and verification, as they feel these actions expose to the world how the U.S. is simultaneously politicizing and undermining the system of inspection and voluntary verification. Moreover, hard-liners would like to see the IAEA push Iran to make greater concessions, purely in order to increase friction between Iran and the West and establish an adversarial relationship with the IAEA. At the same time, however, they would also like Iran to acquire more technically sophisticated components, using all of the loopholes allowed under the statutes of the Nonproliferation Treaty (NPT) and the Comprehensive Test Ban Treaty (CTBT).

Moderates in Iran feel the global community should follow the rules, and that political uses of the IAEA should be abandoned. Ali Khorram, of the Institute for Political and International Studies, in observing IAEA challenges to Iran's veracity, has concluded, "This is a true crisis situation for Iran." IAEA activity must be impartial, proficient, and credible. Moderates have sought to discourage the IAEA from giving the U.S. a technical role in its work. They demand that the IAEA only apply laws under statutes that exist in treaties that are currently in effect. They feel that resolutions are being made solely in response to Iran's particular case. There is the sense that there have been endless attempts to implement a double standard, which deeply concerns some moderates as they ponder future relations with the U.S. Mohammad Tajik, president of the Center of Strategic Studies and a formal advisor to President Mohammad Khatami, explained that, "We are committed to the NPT and CTBT, and whatever we do is under those treaties. We have no intention to get out of the NPT and CTBT." Continual U.S. demands for Iran to acquiesce to its policy goals have been detrimental to the moderates' efforts on the nuclear issue; agreeing to such demands would be

2 Personal conversation with A.A. Soltanieh in September 2004.

3 Personal conversation with Mahmood Sariolghalam in Tehran in October 2004.

4 Personal conversation with Ali Khorram in October 2004.

5 Personal conversation with Mohammad Tajik in October 2004. 
counter to their revolutionary ideals. Moderates as well as conservatives appear ready to defend Iran's sovereignty and its right to engage in activities within the scope of its treaty obligations.

In addition, moderates would prefer that Iran continue to allow inspections, and in return the IAEA should allow progress in the field to continue if no violations are found. The moderates have also placed faith in the Non-Aligned Movement in Geneva, which has tabled a complaint to the IAEA Board for review. This complaint notes that Iran has complied with existing treaties, and argues that the actions against it appear politically motivated.

\section{Iraq}

To the Iranians, overall U.S. activities in Iraq demonstrate that military commanders and U.S. policy makers possess "little understanding of the land." This has provided the opponents of the U.S. with a sense of advantage, and tactical errors by the U.S. only serve to enhance that feeling. Beyond failing to understand how to operate in Iraq, the U.S. appears hampered by its broader policy for Iraq of engaging in social engineering. The Iranians firmly believe that any effort to impose a political system on the Iraqi people will not work. The Iraqis, they note, have never accepted systems prescribed for them by other states in the past, and clearly there has been no real support from the Iraqi population for the U.S. approach. If the U.S. fails to abandon its mission of establishing democracy in Iraq, it will likely need to remain entrenched in the country in a quixotic attempt to succeed. U.S. hopes for avoiding such a circumstance have been placed in the January 2005 elections, which even UN Secretary-General Kofi Annan publicly doubted could be free and fair, let alone conducted in an orderly fashion. American hopes have also been bound up in the effort to create an Iraqi security force that could take on some security and stability operations currently carried out by U.S. forces.

Reza Cheginizadeh of the Center of Strategic Studies, who is an advisor to the Expediency Council led by former Iranian President Hashemi Rafsanjani, noted that conservatives and hard-liners in Iran would like to see the U.S. remain in Iraq indefinitely, so that the continuing occupation will feed the flames of Islamic radicalism. If some large-scale breakdown in order in Iraq occurred, the conservatives are convinced that radical elements, such as Moqtada Al-Sadr and his Mahdi army, will take control, making room for the influence of other states. Iran, they believe, would be included among them. The conservatives are opposed to the election process in Iraq. They would prefer that the elections occur as scheduled, with the hope that current or even worse security conditions will cause the elections to fail.

Some moderates are convinced that the project of building democracy in Iraq, which "was a loser from the start," has failed. At the same time, scholars such as Mohammad Tajik would like the planned elections to be "independent and under the [supervision of the] UN without pressure from any country at all. It would not suffice 
for the U.S. to install a central government." Through successful elections, the Iraqis may develop the sense that a viable state can rise out of the ashes of war.

Regarding the training and equipping of Iraqi security forces, moderates sense that U.S. efforts are wrongly focused on the insurgency. Trouble in the Sunni Triangle or the greater $\mathrm{Al}$ Anbar province does present a security concern, but the true threat to Iraq's future remains civil war. It could easily be triggered (many towns, such as Kirkuk, which once possessed a majority Kurdish population, are now dominated by Shi'a). Moderates also feel that the U.S. should establish security using regional partners, including Iran, but with the caveat that the U.S. must act in good faith in developing such partnerships.

\section{Israel}

Many in Iran theorize that Israel may attack nuclear facilities in Iran, as it did in Osirak, Iraq, in 1981, which would very possibly result in a conflict with both Israel and the U.S. By all accounts, Israel has been arming itself for a conflict, and the U.S. has been supplying Israel with conventional arms. Furthermore, the U.S.- and the global community in general - have closed their eyes to Dimona, the alleged Israeli nuclear weapons facility. Iranians sense that Israel has been afforded "special rights" by the U.S. (many Iranians remember from the era of Shah's regime what having "special rights" from the U.S. means). In their mind, the U.S. has taken a one-sided approach to Israel, an unreasonable position if the goal is regional security and stability.

Many Iranian conservatives are convinced that the U.S. will use Israel as its proxy in an attack on Iran. In response, they would retaliate, ending the problem once and for all. Indeed, conservatives are prepared to act by blanketing Israel with Shahab-3 rockets. In August 2004, Vice Admiral Ali Shamkhani, the Iranian Minister of Defense, explained that Iran might resort to pre-emptive strikes to prevent an attack on its nuclear facilities. ${ }^{7}$ The commander of the Revolutionary Guard, General Mohammed Bager Zolqadr, also stated in August that, "If Israel fires one missile at Bushehr atomic power plant, it should permanently forget about the Dimona nuclear center, where it produces and keeps its nuclear weapons."

Moderates see opportunities for a peaceful resolution of problems between Israel and Iran. Mahmood Sariolghalam of the National University of Iran went so far as to state that "90 percent of the problems Iran has with the U.S. have to do with the Israel issue." Mohammad Tajik went further, stating "the current regime in Israel has caused a kind of harm to the U.S. among countries in the region." ${ }^{\text {"10 }}$ Moderates sense that if Iran abandoned the status quo and adopted a less hostile policy toward Israel, the U.S. would define the Iranian issue differently. Yet, for that to ever happen, Israel must ac-

\footnotetext{
Personal conversation with Mohammad Tajik in October 2004.

The New York Times, August 20, 2004, p. 4.

Ibid.

9 Personal conversation with Mahmood Sariolghalam in October 2004.

10 Personal conversation with Mohammad Tajik in October 2004.
} 
cept Iran's sovereignty, and must not use its considerable political influence in the U.S. to prevent it from having the same rights as other states. Fairness can only be established through a change in course. Due to the lack of any cooperation, Iran will maintain its distance, and will not change its position on Israel.

\section{U.S. Policy on the Middle East}

The stated goal of U.S. policy in the Middle East is to establish democracy in the region. However, the United States' implementation of this policy has been confused and uncertain. Iranians generally feel that U.S. policy has had a destructive effect in the region; the Bush Administration's actions in Iraq have simply given democracy a bad name. No state in the region supports the idea that democracy can be imposed by force. The idea of regime change as being central to the U.S. approach to establishing democracy among Middle Eastern states is viewed as overtly threatening by the leaders of those states.

Many Iranian conservatives conclude that current U.S. policy on, and recent U.S. actions in, the Middle East are simply a manifestation of a concealed agenda of engaging in a great crusade against Islam. This sense that an anti-Islamic bias drives U.S. regional policy provides further fuel to radical Islamism. It is the dream of hard-liners that a clash between the Western and Islamic worlds would occur. Indeed, conservatives in Iran are not intimidated by U.S. military power. The oversimplification of U.S. policy and decision-making related to Iran has perhaps led to the underestimation of Iran's true capacity to harm the U.S. and its interests. This may account for statements emanating from U.S. officials that appear to have the objective of provoking the Iranians to take hostile action against the U.S. If the U.S. were to respond to an Iranian attack against Israel, even if Iran acted in self-defense, hard-line elements like the Revolutionary Guards would be ready to strike at U.S. interests worldwide. The goal would be to present a direct challenge to the global hegemony of the United States. Reza Cheginizadeh of the Center of Strategic Studies in Tehran stated that many conservatives feel " $[\mathrm{t}]$ he U.S. can only understand force, it does not listen to powerlessness. If you wish to be listened to by the U.S., you must have a big gun and a big stick." 11

With the U.S. and EU escalating measures in regard to possible sanctions on Iran's nuclear program, moderate officials in Iran have become increasingly concerned over how far things will go. Ali Khorram, a senior expert at the Institute for Political and International Studies of the Ministry of Foreign Affairs, explained that Iran has acquired information suggesting that, "after June 2003, the U.S. began a time-line for an attack against Iran." 12 The degree to which the U.S. has pressed Iran on its nuclear energy program - as well as the crisis created by the U.S. condemnation of Iran for allegedly enriching uranium - has only served to give credence to theories that the U.S. will initiate hostilities at some point.

11 Personal conversation with Reza Cheginizadeh in September 2004.

12 Personal conversation with Ali Khorram in October 2004. 
Nothing that the U.S. has done with regard to Iran has helped moderates push their agenda. It was vocal U.S. support for reformist politicians in the 2004 elections that caused the religious authorities to expel reformists from the election, and many from politics entirely. The U.S. has often rejected proposals aimed at initiating contacts. In the 8 November 2004 issue of Newsweek International, it was revealed that, during the last year, Iran, through Swiss diplomatic channels, offered to exchange members (or lists of members) of Al-Qaida currently held in Iran for members (or lists of members) of the People's Mujahedeen (now ranked twenty-fifth on the State Department's list of thirty-nine foreign terrorist organizations) in U.S. custody. The U.S. showed no interest.

As time passes, the U.S. will sink ever deeper into the quagmire of the Middle East, and will be likely to make more mistakes. Moderates in Iran hope that the U.S. will change course before it is too late. The moderates do not view Iran as a threat to the U.S. Rather, they want U.S. policy makers to recognize that Iran and the U.S. need each other. Some would prefer the U.S. to perceive Iran as a counter-balance to Russia, and as a potential regional power that can also bolster U.S. strategic interests in the region. Some think the first step of the United States should be to negotiate the end of sanctions in exchange for the termination of Iran's nuclear program. Mahmood Sariolghalam expressed the view that "the US government and Iran must take steps toward each other at the same time." $" 13$

\section{U.S. Presidential Election}

Iranian officials - both conservative and moderate - viewed the U.S. presidential election in November 2004 as critical. To conservatives, the U.S. elections represented a measure of the American public's respect for the people of other states. Support for the Bush Administration would indicate that American voters do not desire a change of course or progress. If President George W. Bush had lost his bid for re-election, his administration's actions would be seen as running counter to the people's wishes, and not reflective of them. Iranian conservatives believe that change in the U.S. could occur either through its recognition that the wrong course has been pursued, or through catastrophe. As Reza Cheginizadeh explained, hardliners feel that only through catastrophe would the American people "see the light."

Moderates sensed prior to the election that a rapprochement could be reached, regardless of who won. Thus, in spite of the election results, moderates hold out hope that progress can be made in U.S.-Iran relations. The Iranians explain that they have had experiences with both Republicans and Democrats before, and that, except for some stylistic differences, their overall approaches have been consistent. Right now, however, they would like U.S. policy to move from the threat to act preemptively toward a stance of fair and balanced dialogue. U.S. attitudes and actions following the

13 Personal conversation with Mahmood Sariolghalam in October 2004.

14 Personal conversation with Reza Cheginizadeh in September 2004. 
IAEA's next report on Iran has provided some indication whether there will be cooperation or confrontation. Moderates, of course, were hoping for cooperation.

\section{Conclusion}

In order for any dialogue to be established, the U.S. must begin by sending the right signals to Iran. Threats by American officials have been met with recalcitrance, and tend to galvanize public opinion in Iran against the U.S. Furthermore, U.S. media dominance and expertise in public relations ensures that U.S. positions, admonishments, and threats will be heard worldwide. American officials may feel the media is a safe, non-threatening vehicle for making such statements. However, Iran lacks the media capabilities of the U.S. government, and does not really want to use the media as a tool to exchange views with the U.S. Words from Washington are taken at face value in Tehran, and have served only to motivate conservatives and hard-liners to prepare for war.

If true evidence of treaty violations is ever found, the U.S. could hardly be asked to attempt to accommodate Iran. However, absent such evidence, it is unreasonable to continue to take steps that may poison the environment for a peaceful resolution of the current crisis. The ongoing situation in Iraq has done enough to convince many Iranians that U.S. intentions are not peaceful. Given the perspectives of moderate Iranians, such as those presented here, it is clear that they possess the requisite views and willingness to open a dialogue with the United States. In seeking contact with moderates, the U.S. should not expect immediate pronouncements in favor of its positions. Though they may have the ear of Iran's religious leadership, the moderates' political position is still weaker than that of the conservatives and hard-liners. Rather, they might assist the process of improving U.S.-Iran relations by providing more realistic approaches to effect change and find peaceful resolutions to issues. Indeed, through a positive dialogue, the moderates may make suggestions on the nuclear energy issue, but also on others, such as Iraq and terrorism. As A.A. Soltanieh, of the Ministry of Foreign Affairs, explained, "Iran had not originally planned to enrich uranium and terminated reprocessing ten years ago." 15 That point may be crucial in understanding Iran's intent and Iran's position. Moderates want to see a stable Iraq on their border, and may even seek to partner with the U.S. to support efforts to bring security and stability to Iraq. New offers to exchange terrorists may also be made.

The U.S. can either foster or destroy the opportunity to work with Iranian moderates. Without any communication whatsoever, a conflict between the U.S. and Iran becomes more likely. Thus, the final choice for war or peace really lies within U.S. hands. The initiation of small steps may lead to substantial changes. Making the transition to this approach will not be easy for either side. Before military options are selected and plans are initiated, full consideration must be given to finding peaceful solutions. For U.S. policy makers in particular, it would be best, given existing U.S. commitments globally and overall U.S. security, to ensure that American military

15 Personal conversation with A.A. Soltanieh in September 2004. 
THE QUARTERLY JOURNAL

power is used economically. When possible, more effective and efficient ways of resolving issues must be explored. 